FACTA UNIVERSITATIS

Series: Economics and Organization Vol. 18, No 4, Special Issue, 2021, pp. 383 - 396

https://doi.org/10.22190/FUEO210617027R

Original Scientific Paper

\title{
INTANGIBLE ASSETS IMPACT ON SUSTAINABLE GROWTH RATE OF ENTERPRISES IN THE REPUBLIC OF SERBIA
}

\author{
UDC 330:004.7(497.11)
}

\begin{abstract}
Amer Rastićc ${ }^{*}$, Tatjana Stevanović ${ }^{2}$, Ljilja Antić
${ }^{1}$ Business College of Applied Studies" Prof. PhD Radomir Bojković”, Kruševac, Serbia ${ }^{2}$ University of Niš, Faculty of Economics, Niš, Serbia
ORCID iD: Amer Rastić $\quad$ (iD) N/A
Tatjana Stevanović (iD) https://orcid.org/0000-0003-1270-7129

Ljilja Antić $\quad$ (iD) https://orcid.org/0000-0001-8796-4619

Abstract. The digital economy unites a dual typology of resources in enterprises, which can be tangible and intangible. In the language of accounting, it is about tangible and intangible assets. Due to the involvement of digital technologies in companies, intangible assets or intellectual capital became prominent. The sustainable growth of companies in Serbia has great importance for both management and external stakeholders. The presented paper examines the impact of intangible assets, formatted with the VAIC model, on the Sustainable growth rate (SGR) of companies in Serbia. The selected list of companies refers to the most profitable industry sector of the Serbian economy, assessed according to the Serbian Business Registers Agency for 2018. In order to confirm the hypothesis, the synthesis method, the analysis method, and the correlation analysis method were used. There was a significant positive impact of intangible assets on the sustainable growth rate of enterprises and a negative impact of physical assets, which, however, is not statistically significant. Since no research has been recorded in our country that sheds light on the correspondence between intangible assets and SGR, the study has a strong practical significance for this purpose. These results represent at the same time a reference point for our economy and for future entrepreneurs on the way to intensive involvement of intangible assets in companies.
\end{abstract}

Key words: intangible assets, digital economy, sustainable competitive advantage, sustainable growth rate

JEL Classification: Q56

Received June 17, 2021 / Revised September 27 / Accepted November 21, 2021

Corresponding author: Amer Rastić

* PhD student at University of Niš, Faculty of Economics, Serbia

Business College of Applied Studies „Prof. PhD Radomir Bojković“, Topličina 12, 37000 Kruševac, Serbia

| E-mail: amerstudent@hotmail.com

ㄷ 2021 by University of Niš, Serbia | Creative Commons Licence: CC BY-NC-ND 


\section{INTRODUCTION}

The role and importance of intangible assets strongly correspond to the emergence of the digital economy or Industry 4.0. In other words, Industry 4.0 is determined by the process of digitization and the connection of digital and physical objects (so-called cyberphysical systems). It was first promoted by the German government in 2012 (germ. Industrie 4.0) as a progressive step in the digitalization of German society (see more Cagle et al., 2020, p. 106; Pozdnyakova et al., 2019, p. 12, 17; Sukhodolov, 2019, pp. 310). Industry 4.0 is characterized by extensive automation, robotization in the production and service sphere, increasing workforce efficiency and efficiency in companies in general, reducing the anthropological impact on the environment through the use of economical technology, and increasing demand for high intellectually capable workforce, especially in information technology (Prokofyev et al., 2019, p. 95).

Current technology of the digital economy refers to Big Data, Blockchain, Cloud technology, Internet of Things (IoT) or a network of various devices where data is an object of exchange, and artificial intelligence (AI), which refers to computer systems capable of performing tasks that require human intelligence. In addition, the digital economy involves Virtual Reality or computer-simulated environment technology and Ubiquitous Computing technology. Ubiquitous computing is defined as connected computer systems in the environment in which we live and work, such as devices in smart houses (Popkova \& Haabazoka, 2019, p. 8). However, employees still represent the main carriers of economic activities, whose knowledge converges towards digital knowledge (Popkova \& Haabazoka, 2019, p. 7).

This makes it clear that knowledge and information represent the starting point for creating the resources and values of today's economy. Accordingly, the assets of business entities are increasingly knowledge-intensive (Ghosh \& Mondal, 2009, p. 369). In other words, in the digital knowledge economy, economic value is mainly derived from intangible assets, to a much greater extent than from physical assets (Chu et al., 2011, p. 249). This is particularly attributable to the European economic context (Sardo \& Serrasqueiro, 2017, p. 771). It is, according to Stewart, "something that cannot be touched, yet slowly makes you rich" or, according to Sullivan, "knowledge that can be converted into profit" (Ghosh \& Mondal, 2009, p. 370).

The competitiveness of the company is therefore established in the patterns of intangible assets exploitation. Sustainable competitive advantage is largely determined by a company's sustainable growth rate (SGR). SGR can be also associated with economic, environmental, and social initiatives to secure the future (Xu et al., 2020, p. 2).

The work is organized as follows. After the introduction, a review of the literature was presented, followed by a theoretical explanation of the relationship between intangible assets and sustainable enterprise growth rates, and research hypotheses were proposed. The next part is dedicated to the empirical analysis of the data, followed by a discussion of the obtained results. The final part of the paper includes concluding remarks. 


\section{LITERATURE REVIEW}

\subsection{Intangible assets}

Knowledge resources have rapidly become important in many disciplines such as accounting, economics, and strategic management (Asiaei, Jusoh \& Bontis, 2018, p. 294). The literature noted relatively early texts on the importance of intangible assets. Swedish economist Westerman (1768) points out that the Swedish transport industry at that time lagged behind the main competitors due to lack of professional knowledge (Serenko \& Bontis, 2013, p. 478).

Clear guidelines for the development of intangible assets were established by Penrose as the founder of resource-based theory in 1959 (although the name resource-based theory is mentioned in 1984 in Wernerfelt's work, "Resource Based View of the Firm") in her work "The Growth of the Firm". Instead of perceiving companies as administrative units, Penrose described the company as a resource base made available to managers. Hence, it was concluded that competitive advantage is provided by ownership of certain key resources that are rare (Pike, Fernström \& Roos, 2005, p. 490).

Increased corporate investments in intangible assets include, in addition to investments in pure forms of intangible assets, the intangible enrichment of the value of manufactured products and provided services (Mehta \& Madhani, 2008, p. 11). According to the methodology of resource-based theory, intangible assets are viewed as equal to physical and financial assets (Gupta \& Raman, 2020, p. 51). For creating value that is a consequence of investments in intangible assets, and in order to achieve a competitive advantage of the company, extraction of the given value is also required. By extraction, or extraction of the value of intangible assets, is meant primarily its conversion into monetary value.

Thus, achieving a competitive advantage in the digital economy has been redefined by the impact of digital technology and market globalization. In the new circumstances, there is a vertical disintegration, accentuation of innovations, and intensive use of informatics technologies. In other words, this process has produced the accumulation of intangible assets reflected in innovations, employees, and organization (Ciprian et al., 2012, p. 683). Finally, it is pointed out that intangible assets represent the most potent position of assets that affect value creation (Đuričin \& Janošević, 2009, p. 10).

In the context of creating and using knowledge, companies in order to achieve a competitive advantage, focus on the following areas (adapted to Novićević, Antić \& Stevanović, 2006, p. 9):

i. Computer and communication technologies (AI, Big Data, IoT, Blockchain, Cloud technology, virtual reality, versatile computing and 3D printing),

ii. Analytical methods (which involve intelligent analytical softwares).

Intangible assets, or in management terminology "intellectual capital", are in the literature, albeit unofficially, divided into three parts: human capital, structural capital, and relational capital (Cabrilo \& Dahms, 2018, pp. 621-648; Wang et al., 2016 pp. 1861-1885). Gupta and Raman (2020) emphasize that the term "intangible assets" is attributable to accounting, while the term "intellectual capital" is present in the science of human resources management. The term "knowledge resources" exists between economists in general (Gupta \& Raman, 2020, p. 49). The separation of terms according to the field of study has been respected in academic texts (Naidenova \& Parshakov, 2013, p. 640).

According to Bontis et. al., human capital is manifested as an individual stock of knowledge in an organization that results from employees (Bontis et al., 2000., p. 87). Also, 
Bontis et. al., indicate that human capital is the primary component of intangible assets as a value creator. The management of this capital is attractive in the sense of its conversion into a sustainable competitive advantage through increased business performance (Bontis \& Fitzenz, 2002, pp. 225, 227). We also notice that these assets are profiled in economics textbooks as "Key competencies" or as "Core competencies" as the main strategic determinant for achieving a sustainable competitive advantage (Michalisin et al., 1997, p. 374; Novićević, Antić \& Sekulić, 2006, p. 41).

Capital that supports infrastructure for employees is interpreted as structural capital (Chowdhury, Rana \& Azim, 2019, p. 787). Structural capital refers to databases, software platforms, algorithms, codes, organizational structure, documentation, and business processes or "everything of knowledge that remains in the company, after the end of the working day" (Bontis et al., 2000, p. 88). Relational capital refers to the company's relations with consumers and suppliers, includes distribution channels, brand and everything that creates and maintains the company's intangible assets by involving the company in interaction with the external environment. It "includes knowledge materialized in all the relationships that a company develops with suppliers, trade associations or the government." (Bontis et al., 2000, pp. 88-89).

The question is, how to calculate intangible assets and how to quantify their impact? Among many models that exist, the frequently cited model for calculating intangible assets is the VAIC model (VAIC is an abbreviation for Value Added Intellectual Coefficient). The model represents one of the most significant contributions in the valuation of intangible assets (Gupta \& Raman, 2020, p. 50).

The VAIC model is based on the fact that the exploitation of physical and intangible assets creates added value (VA). VA implies the difference between output and input values. The output value, represents the value of total income, and the input value includes all costs except employee costs, which are treated as intangible assets of the enterprise (Andriessen, 2004, p. 365).

Specifically, VA can be determined as the sum of operating profit, investments in human resources, and depreciation costs (of fixed assets and intangible assets) (Dzenopoljac et al., 2017, p. 888):

$$
V A=\text { Operating profit }+ \text { Employee costs }+ \text { Depreciation }
$$

One of the weak points of the VAIC model is the condition that the company that is involved in the calculation needs to have a positive profit. If there are losses, according to the VAIC model it means that the company doesn't create new added value (for more see Chu et al., 2011, p. 252-253).

Capital employed (CE) refers to the value of net assets and includes physical and financial capital, or in other words, tangible capital. CE is used to start and maintain a business. Tangible assets in this sense play a fundamental role in determining the value of a company (Dzenopoljac et al., 2017, p. 888). Capital Employed Efficiency (CEE) is calculated as the ratio of balance sheet net assets and value-added VA (Dzenopoljac et al., 2017, p. 888):

$$
C E E=\frac{C E}{V A}
$$

HCE (Human Capital Efficiency) is calculated as ratio between VA and investments in human resources (employee costs) (Dzenopoljac et al., 2017., p. 888): 


$$
H C E=\frac{V A}{H C}
$$

Structural Capital Efficiency (SCE) is calculated as ratio between SC and VA. For the calculation of SC, the value of HC is subtracted from VA (Dzenopoljac et al., 2017, p. 889):

$$
\begin{gathered}
S C E=\frac{S C}{V A} \\
\mathrm{SC}=\mathrm{VA}-\mathrm{HC}
\end{gathered}
$$

Dzenopoljac et. al. (2017) state that it is not difficult to notice that the sum of HCE and SCE represents the total efficiency of intangible assets (ICE, Intellectual Capital Efficiency). The rationalization of the model is based on the assumption that companies with a higher ICE ratio exploit intangible assets more efficiently and, consequently, have a higher amount of intangible assets (Dzenopoljac et al., 2017., p. 889).

\subsection{Sustainable growth rate of the company}

The sustainable growth rate of the company is a very important business and financial performance of the company, especially in situations of economic imbalance. Otherwise, SGR refers to the maximum and consistent growth rate that a company can achieve without mobilizing additional funds in the form of borrowing. Growth below a sustainable growth rate can affect the loss of a company's competitive advantage due to reduced business efficiency. Growth above a sustainable growth rate involves additional borrowing by the company, which can worsen its financial health (Stanić, 2015, p. 118). In other words, this represents a short-term expansion of sales growth because such a goal is ultimately unsustainable. Accelerated growth overloads corporate resources and requires new borrowing in order to prevent corporate insolvency (Xu et al., 2021).

An increase in debt while maintaining the same level of insolvency can only be implemented if the increase in the percentage of debt in total sources is equivalent to the increase in the percentage of capital. The growth rate is therefore a complex long-term indicator that belongs to the business and financial performance of the company. Any growth that deviates from a sustainable growth rate can be considered unsustainable growth (Xu et al., 2021).

The expression of SGR is clarified through several modalities, among which the most famous is the first, Higgins model of SGR. In a more concise edition, according to Higgins (1977), SGR is expressed as (Arora, Kumar \& Verma, 2018).

$$
\mathrm{SGR}=\mathrm{ROE} \text { (Return on Equity) x b (Retention Rate) }
$$

ROE indicator is an indicator with a long tradition and is calculated as:

$$
R O E=\frac{\text { Net profit }}{\text { Shareholders' equity }}
$$


On the other hand, as we know, retention rate $\mathrm{b}$ indicates the number of funds remaining for the company to reinvest in business activities after the payment of dividends. It is calculated as:

$$
b=\frac{\text { Net profit }- \text { payed dividends }}{\text { Net profit }}
$$

\subsection{Intangible assets and SGR}

Studies have concluded that intangible assets are a key element in achieving competitive advantage (Sardo \& Serrasqueiro, 2017; Mention \& Bontis, 2013; Zéghal \& Maaloul, 2010). In other words, intangible assets significantly correspond to the business and financial performance of the company. These studies, which involve researches of relationship between intangible assets and business-financial performance, shed light on the impact of intangible assets on short-term indicators of performance in companies. SGR, however, is an accounting measure that covers a longer period of time and business-financial expansion of the company. Consequently, for the realization of SGR and, ultimately, sustainable competitive advantage, it is necessary for companies to create value by exploiting intangible assets.

A study by $\mathrm{Xu}$, et. al. (2020) examined the impact of intangible assets on the sustainable growth rate of agricultural smart high-tech and non-high-tech enterprises in China. The results obtained suggest that human capital reflects the main impact on the SGR. In another study (Xu et al., 2021), a sample based on Chinese companies in the field of tourism, agriculture, and renewable energy industry was selected. The study concludes that physical and intangible assets reflect a positive impact on the sustainable growth of the company. In the context of intangible assets, the intensity of the positive impact is distributed primarily on human capital, then structural and to a lesser extent relational capital.

A study that covers India's evidence investigated the impact of intangible assets in India's enterprises on their sustainable growth rates. The results of the study indicate a positive significant impact of all variables of intangible assets on a sustainable growth rate. Intangible assets in this study are represented in a slightly modified edition. Intangible assets in this study are constituted from physical capital, human capital, relational capital, innovation capital, and process capital (Mukherjee \& Sen, 2019).

A study from 2008, conducted in China, proved the positive significant impact of intangible assets (intellectual capital) on SGR, where, according to results of this study, "human capital is the root of the momentum of enterprise growth" (Shui-ying \& Ying-yu, 2008).

The study, which covers Korea's evidence, also demonstrated the positive impact of intangible assets, more specifically human and relational capital, on the sustainable growth of manufacturing companies. The positive impact of physical assets on the sustainable growth of these companies has also been proven (Xu \& Wang, 2018). Investments in physical assets are inseparable from investments in intangible assets. In other words, it is necessary to involve physical assets in this consideration when we are trying to measure the impact of intangible assets on sustainable growth.

Although SGR has not been the subject of such studies, according to previous studies related to other business and financial performance, companies in Serbia are still insufficiently exploiting intangible assets, materialized in innovation, employees and organization of the company, to achieve a sustainable competitive advantage (Dženopoljac et. al., 2016). 


\subsection{Proposed hypotheses}

According to the previous text, using the mathematical formats listed above, the impact of intangible assets on SGR can be explained through the main and auxiliary hypotheses:

Hypothesis H1. There is a positive impact of intangible assets on SGR;

$H$ Ha. Companies with a higher ICE ratio have a higher rate of sustainable growth SGR;

HIb. Companies with a higher CEE ratio have a higher rate of sustainable growth SGR.

Or if we draw an overview of these relations (Figure 1):

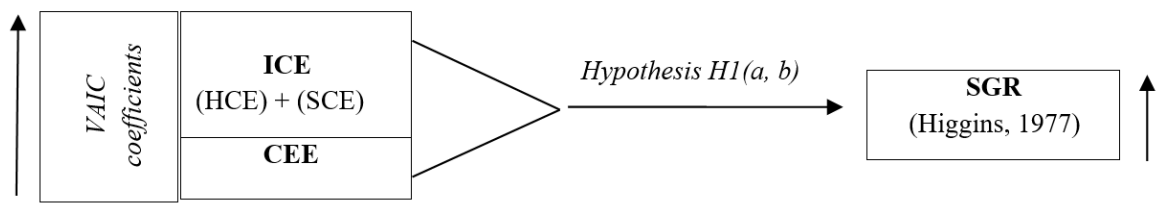

Fig. 1 Overview of Hypothesis H1

Source: Authors own drawings

Finally, this research aims to find a valid conclusion about Hypothesis 1 . Precisely, the aim is to verify how much the intangible assets of the company, formatted by the VAIC model, are an influential predictor of the sustainable growth rate, formatted by Higgins (1977), of the company.

\section{MethodOLOGY}

\subsection{Data source}

To check the validity of Hypothesis 1, it is necessary to select the data source and select a suitable sample. In obtaining a suitable sample of companies to test Hypothesis 1, we were guided by the following prerequisites:

- sample needs to contain companies that reported significant net profit result during the observed period, that is, the leaders are in their branch;

- companies in the sample are knowledge-intensive with a relatively high share of balance sheet reported intangible assets, such as labor costs, development investments, and research and development costs;

- the financial statements of the selected companies in the sample were previously audited.

Considering these preconditions, the database for sample selection, which is published by the Serbian Business Registers Agency (SBRA) in its annual publication for 2018, is suitable.

These publications are reports of the "100 most companies” (Serb. „Izveštaj o sto naj privrednih društava") which are issued for each year. At the time of making this research, we were not able to download the publication for 2019, and we used a list of companies in this publication published for 2018 including their financial statements for 2019. There is a database in the form of a list that involves companies that have achieved the highest 
annual net profit for the period. With the elimination of companies that do not have complete financial statements for the period, a sample of 67 companies that achieved the highest net profit in 2018 is selected (Table 1).

Table 1 Selected list of companies

\begin{tabular}{lll}
\hline 1. Naftna Industrija Srbije, NIS & 23. Farmina Pet Foods & 45. Delta Agrar \\
2. Telekom Srbija & 24. Imlek & 46. Apatinska Pivara \\
3. Telenor, Beograd & 25. Koteks Viscofan & 47. Luxury Tannery \\
4. Javno preduzeće Srbijagas & 26. Frikom & 48. Fabrika Hartije \\
5. Tigar Tyres & 27. JP Elektroprivreda Srbije & 49. Impol Seval \\
6. JKP Beogradske elektrane & 28. CRH Srbija & 50. JP Srbijašume \\
7. Coca-Cola & 29. Agromarket & 51. Milan Blagojević-Namenska \\
8. Philip Morris & 30. Heineken Srbija & 52. Pharmaswiss \\
9. SBB & 31. Titan Cementara & 53. Phuket \\
10. Hemofarm & 32. Karin Komerc & 54. Marbo \\
11. Matijević & 33. Sport Vision & 55. OMV \\
12. Real Knitting & 34. Contitech Fluid & 56. Atlantic Grand \\
13. Delhaize & 35. Ball & 57. Naftagas \\
14. JP Jugoimport & 36. Almex & 58. HD-Win \\
15. Elektromreža Srbije & 37. Pink & 59. Zdravlje \\
16. Tetra Pak & 38. Peštan & 60. Elixir \\
17. JP Pošta Srbije & 39. Yugoroskaz & 61. Galenika \\
18. Henkel Srbija & 40. RZD International & 62. Phiacademy \\
19. Lafarge & 41. Direct Media & 63. Forma Ideale \\
20. Mozzart & 42. Metalfer & 64. Knjaz Miloš \\
21. Bambi & 43. Soko Štark & 65. Sport Time Balkans \\
22. Messer Tehnogas & 44. Drenik & 66. Mladost \\
& & 67. Auto Čačak \\
\hline
\end{tabular}

Source: Authors made a suitable list of companies according to SBRA - The Serbian Business Registers Agency. (2020). STO NAJ... privrednih društava u 2018. godini [The top hundred enterprises in 2018]. Retrieved from https://www.apr.gov.rs/upload/Portals/0/GFI\%202019/STO_NAJ/STO_NAJ_2018_16102019.pdf

The sample includes financial statements (balance sheets and income statements) of these companies for the period 2015-2019. We collect relevant financial statements for this period manually inputting identification numbers or names of companies in the SBRA (2020) search engine. Companies that didn't publish financial statements for the given period or realized negative operating profit were eliminated from the study.

\subsection{Construction of the regression model}

To test Hypothesis H1, it is necessary to construct a regression model. Constructing a regression model requires the involvement of a dependent variable and independent variables in a regression equation with a specific constellation of relationships between variables. The dependent variable refers to the SGR. The independent variables are formatted with the VAIC model and refer to ICE and CEE. The construction of the regression model according to the equation looks like:

$$
\text { SGRi, } t=\beta_{0}+\beta_{1} I C E i, t+\beta_{2} C E E i, t+\varepsilon i, t
$$


More precisely, using the technique of multiple standard regression analysis based on specified regression model, it is possible to determine (adapted according to Pallant, 2009, p. 147):

- how well the variables ICE and CEE can predict the outcome of the SGR in the sample;

- which variable (ICE or CEE) best predicts the SGR in the sample;

- after eliminating the impact of other variables, how much particularly, the selected intangible asset, can predict an outcome of the SGR enterprise.

\subsection{Research results}

\subsubsection{Descriptive statistics and correlation analysis}

According to Table 2, the average SGR value is 16.74 . When we talk about intangible assets efficiency coefficient (ICE), it is 4.24. However, this is higher than the efficiency coefficient of physical assets (CEE), which is 0.84 . This actually mildly shapes the initial impression in our analysis that intangible assets have a stronger impact on VA creation.

Table 2 Descriptive Statistics

\begin{tabular}{lccc}
\hline & Mean & Std. Deviation & $\mathrm{N}$ \\
\hline SGR & 16.742801 & 62.6553640 & 335 \\
ICE & 4.2374 & 2.34498 & 335 \\
CEE & .844540 & 1.5264232 & 335 \\
\hline \multicolumn{4}{c}{ Source: Authors own calculations }
\end{tabular}

As an integral element of the preliminary analysis, Table 3. checks the normality of the distribution for the given variables. The values of the variables were found not to be normally distributed. Further, this will shape our next analysis.

Table 3 Normality test results

\begin{tabular}{|c|c|c|c|c|c|c|}
\hline \multicolumn{7}{|c|}{ Tests of Normality } \\
\hline & \multicolumn{3}{|c|}{ Kolmogorov-Smirnov ${ }^{\text {a }}$} & \multicolumn{3}{|c|}{ Shapiro-Wilk } \\
\hline & Statistic & $\mathrm{df}$ & Sig. & Statistic & $\mathrm{df}$ & Sig. \\
\hline$\overline{\text { SGR }}$ & .307 & 335 & .000 & .344 & 335 & .000 \\
\hline ICE & .159 & 335 & .000 & .766 & 335 & .000 \\
\hline CEE & .305 & 335 & .000 & .384 & 335 & .000 \\
\hline
\end{tabular}

Correlation is a more suggestive technique, in that way, it doesn't give definitive answers. It suggests the existence of a possible relationship between variables (Barrow, M. 2009, p. 231). Since the values of the variables are not normally distributed, the correlation analysis was performed based on the Spearman coefficient $(r s)$.

Table 4 contains correlation findings between presented variables in the regression model and reports the following: 
- A weak positive relationship between the ICE coefficient and the dependent variable SGR was identified, where $r s=0.122(\mathrm{p}<0.05)$. In other words, this is the first indication that a higher ICE coefficient also means a higher SGR;

- A medium-strong positive relationship between CEE and SGR was identified, rs = 0.432 ( $p<0.05)$. This also indicates that the higher CEE coefficient also means a higher SGR.

Table 4 Normality test results

\begin{tabular}{lllrrr}
\hline Correlations & & & & \\
& & & \multicolumn{1}{c}{ SGR } & \multicolumn{1}{c}{ ICE } & \multicolumn{1}{c}{ CEE } \\
\hline Spearman's rho & SGR & Correlation Coefficient & 1.000 & $.122^{*}$ & $.432^{* *}$ \\
& & Sig. (2-tailed) &. & .025 & .000 \\
& & $\mathrm{~N}$ & 335 & 335 & 335 \\
\cline { 2 - 5 } & ICE & Correlation Coefficient & $.122^{*}$ & 1.000 & -.034 \\
& & Sig. (2-tailed) & .025 & .5 & .533 \\
& $\mathrm{~N}$ & 335 & 335 & 335 \\
\cline { 2 - 6 } & CEE & Correlation Coefficient & $.432^{* *}$ & -.034 & 1.000 \\
& Sig. (2-tailed) & .000 & .533 &. \\
& $\mathrm{~N}$ & 335 & 335 & 335 \\
\hline
\end{tabular}

${ }^{*}$. Correlation is significant at the 0.05 level (2-tailed).

$* *$. Correlation is significant at the 0.01 level (2-tailed).

Source: Authors own calculations

\subsubsection{Analysis of the regression model}

The results of the regression analysis according to Table 5. indicate that the model significantly affects the variability of the variable SGR. According to the amount of the adjusted coefficient of determination (Adjusted $\mathrm{R}^{2)}$ is $2.9 \%$, this model explains $2.9 \%$ of the variability of SGR. In other words, regression model with the coefficients of intangible assets efficiency (ICE) and invested capital efficiency (CEE) explains $2.9 \%$ of changes in SGR.

Table 5 Explanatory power of the model

\begin{tabular}{|c|c|c|c|c|c|c|c|c|c|}
\hline \multicolumn{10}{|c|}{ Model Summary $^{\mathrm{b}}$} \\
\hline \multirow[b]{2}{*}{ Model } & \multirow[b]{2}{*}{$\mathrm{R}$} & \multirow[b]{2}{*}{ R Square } & \multirow[b]{2}{*}{$\begin{array}{l}\text { Adjusted R } \\
\text { Square }\end{array}$} & \multirow[b]{2}{*}{$\begin{array}{l}\text { Std. Error of } \\
\text { the Estimate }\end{array}$} & \multicolumn{5}{|c|}{ Change Statistics } \\
\hline & & & & & $\begin{array}{l}\text { R Square } \\
\text { Change }\end{array}$ & F Change & df1 & $\mathrm{df} 2$ & $\begin{array}{c}\text { Sig. F } \\
\text { Change }\end{array}$ \\
\hline 1 & $.187^{a}$ & .035 & .029 & 61.7301839 & .035 & 6.043 & 2 & 332 & .003 \\
\hline
\end{tabular}

a. Predictors: (Constant), ICE, CEE

b. Dependent Variable: SGR

Source: Authors own calculations

The explanatory power $(2.9 \%)$ is not high. However, the model is statistically significant for $\mathrm{p}<0.05$ (Table 6). 
Table 6 Statistical significance of the model

\begin{tabular}{|c|c|c|c|c|c|c|c|}
\hline \multicolumn{8}{|c|}{$\mathrm{ANOVA}^{\mathrm{a}}$} \\
\hline Model & & Sum of Squares & df & Mean Square & $\mathrm{F}$ & & Sig. \\
\hline \multirow[t]{3}{*}{1} & Regression & 46057.627 & 2 & 23028.814 & & 6.043 & $.003^{\mathrm{b}}$ \\
\hline & Residual & 1265124.382 & 332 & 3810.616 & & & \\
\hline & Total & 1311182.010 & 334 & & & & \\
\hline
\end{tabular}

a. Dependent Variable: SGR

b. Predictors: (Constant), ICE, CEE

Source: Authors own calculations

The next typical step in interpreting the results of regression analysis is to interpret whether the independent variables (ICE, CEE) in the model make an individual and isolated contribution to the change in SGR (Table 7).

Table 7 Individual contribution of independent variables (ICE, CEE) to SGR in the model Coefficients $^{\mathrm{a}}$

\begin{tabular}{|c|c|c|c|c|c|c|c|c|c|c|c|c|}
\hline \multirow[b]{2}{*}{ Model } & \multicolumn{2}{|c|}{$\begin{array}{l}\text { Unstandardized } \\
\text { Coefficients }\end{array}$} & \multirow{2}{*}{$\begin{array}{c}\text { Standar } \\
\text { dized } \\
\text { Coeffic } \\
\text { ients } \\
\text { Beta } \\
\end{array}$} & \multirow[b]{2}{*}{$\mathrm{t}$} & \multirow[b]{2}{*}{ Sig. } & \multicolumn{2}{|c|}{$\begin{array}{c}95.0 \% \\
\text { Confidence } \\
\text { Interval for B }\end{array}$} & \multicolumn{3}{|c|}{ Correlations } & \multicolumn{2}{|c|}{$\begin{array}{l}\text { Collinearity } \\
\text { Statistics }\end{array}$} \\
\hline & B & $\begin{array}{l}\text { Std. } \\
\text { Error }\end{array}$ & & & & $\begin{array}{l}\text { Lower } \\
\text { Bound }\end{array}$ & $\begin{array}{l}\text { Upper } \\
\text { Bound } \\
\end{array}$ & $\begin{array}{l}\text { Zero- } \\
\text { order }\end{array}$ & Partial & Part & $\begin{array}{c}\text { Toleran } \\
\text { ce }\end{array}$ & VIF \\
\hline 1 (Constant) & .046 & 7.231 & & .006 & .995 & -14.177 & 14.270 & & & & & \\
\hline ICE & 4.563 & 1.440 & .171 & 3.168 & .002 & 1.729 & 7.396 & .171 & .171 & .171 & 1.000 & 1.000 \\
\hline $\mathrm{CEE}$ & -3.123 & 2.213 & -.076 & -1.411 & .159 & -7.476 & 1.230 & -.077 & -.077 & -.076 & 1.000 & 1.000 \\
\hline
\end{tabular}

a. Dependent Variable: SGR

Source: Authors own calculations

Standardized beta coefficients for independent variables indicate their individual and isolated contribution to the dependent variable. In the given model, the standardized beta coefficient for ICE is $\beta_{1}=0.171$. In other words, intangible assets compressed in the ICE reflect a significant positive impact on the SGR variable. The Hypothesis la is confirmed. In other words, a higher ICE also means a higher SGR.

The impact of CEE on SGR is negative, but not statistically significant. Hypothesis $1 b$ is not confirmed. In other words, a higher CEE does not necessarily mean a higher SGR, but lower SGR. Additionally, this relationship is negative, but this is not confirmed with statistical significance.

Finally, we can state that Hypothesis $\mathrm{Hl}$ is partially confirmed, because ICE reflects the positive impact on SGR and CEE does not reflect a positive statistically significant impact on SGR.

\subsubsection{Useful implications of research results}

The results unequivocally indicate a statistically significant positive relationship between the efficiency of intangible assets usage (ICE) and the sustainable growth rate SGR of companies. These findings are consistent with research that $\mathrm{Xu}$ et al. (2021) conducted. However, the impact of CEE on SGR is negative and not statistically significant, which is not consistent with research that Xu et al. (2021) and Xu \& Wang, 2018) conducted because they 
proved positive impact of CEE on SGR. The usefulness of these conclusions can be converted into instructions for business entities.

Management structures in companies are advised to be more aware of intangible assets and increase their investments, especially in human and structural capital (ICE). As Xu et. al. (2021, p. 11) stated, the sustainable growth of modern enterprises should rely more on intellectual capital than on capital employed. Specifically to each company, managers should strengthen the logic of creating intangible assets like developing more employee supportive corporate culture and promoting R\&D activities to build innovations. Also, managers need to incorporate information technology through different initiatives. On the other side, because capital employed is synergistically connected with intellectual capital, managers should also improve the efficiency of CEE in order to make an additional positive impact on SGR. Additionally, managers should reduce the scale of liabilities in companies. To cover these processes, developed management accounting infrastructure is necessary for the assessment of the intangible assets exploitation efficiency. In this way, management is further referred for corrective actions in order to optimize these processes related to intangible assets.

\subsubsection{Limitations of the conducted research}

Despite the best intention to proceed the research in the absence of certain limitations, the obtained results are acceptable having in mind certain limitations. The limitations, however, do not undermine the essentials to which the results of the analysis refer. The first limitation relates to sample size. We believe that with a larger sample in the analysis, results will more strongly emphasize found links between ICE, CEE, and SGR. Second, the VAIC model has its limitations, which are also involved in the given research. VAIC model doesn't cover relational capital, also, the VAIC model doesn't include R\&D costs within structural capital (for more see Chen, Cheng \& Hwang, 2005, p. 162). Third, intangible assets can be hardly represented by a simple sum of components due to their synergistic nature.

\section{CONCLUSION}

Intangible assets strongly correspond to the digital economy and Industry 4.0. and with the development of AI, Big Data, Cloud computing, Virtual Reality, etc. Thus, knowledge becomes the main source of value creation in companies. The sustainable competitive advantage of an enterprise is established on the patterns of intangible assets exploitation rather than on the exploitation of physical assets. Sustainable competitive advantage is closely related to the sustainable growth rate of the company. The sustainable growth rate of a company is also associated with economic, environmental, and social initiatives in securing the future.

In this paper, research was conducted which sheds light on the impact of intangible assets of 67 most profitable companies in Serbia on their sustainable growth rate. Results involves significant positive impact of intangible assets on the sustainable growth rate of the companies. The intangible assets impact is predominant in relation to the impact that reflects physical assets on the sustainable growth rate of the observed companies. This identification represents a contribution in relation to previous research conducted in relation to intangible assets. Also, it represents an incentive for managers of companies in Serbia to focus more intensively on intangible assets creation and exploitation. This is especially due to the evidence in this research that intangible assets provide a better sustainable growth rate for companies. 


\section{REFERENCES}

Andriessen, D. (2004). Making sense of intellectual capital: designing a method for the valuation of intangibles. Butterworth-Heinemann.

Arora, L., Kumar, S., \& Verma, P. (2018). The Anatomy of Sustainable Growth Rate of Indian Manufacturing Firms. Global Business Review, 19(4), 1050-1071. https://doi.org/10.1177/0972150918773002

Asiaei, K., Jusoh, R., \& Bontis, N. (2018). Intellectual capital and performance measurement systems in Iran. Journal of Intellectual Capital, 19(2), 294-320. https://doi.org/10.1108/jic-11-2016-0125

Barrow, M. (2009). Statistics for economics, accounting and business studies. Pearson Education.

Bontis, N., \& Fitz-enz, J. (2002). Intellectual capital ROI: a causal map of human capital antecedents and consequents. Journal of Intellectual Capital, 3(3), 223-247. https://doi.org/10.1108/14691930210435589

Bontis, N., Chua Chong Keow, W., \& Richardson, S. (2000). Intellectual capital and business performance in Malaysian industries. Journal of Intellectual Capital, 1(1), 85-100. https://doi.org/10.1108/14691930010324188

Cabrilo, S., \& Dahms, S. (2018). How strategic knowledge management drives intellectual capital to superior innovation and market performance. Journal of Knowledge Management,22(3), 621-648. https://doi.org/10.1108/jkm-07-2017-0309

Cagle, M. N., Yılmaz, K., \& Doğru, H. (2020). Digitalization of Business Functions under Industry 4.0. In Digital Business Strategies in Blockchain Ecosystems., Springer, Cham., p. 105-132.

Chen, M., Cheng, S., \& Hwang, Y. (2005). An empirical investigation of the relationship between intellectual capital and firms' market value and financial performance. Journal of Intellectual Capital, 6(2), 159-176. https://doi.org/10.1108/14691930510592771

Chowdhury, L. A. M., Rana, T., \& Azim, M. I. (2019). Intellectual capital efficiency and organisational performance. Journal of Intellectual Capital, 20(6), 784-806. https://doi.org/10.1108/jic-10-2018-0171

Chu, S. K. W., Hang Chan, K., \& Wu, W. W. Y. (2011). Charting intellectual capital performance of the gateway to China. Journal of Intellectual Capital, 12(2), 249-276. https://doi.org/10.1108/14691931111123412

Ciprian, G. G., Valentin, R., Mădălina, G. (Iancu) A., \& Lucia, V. (Vlad) M. (2012). From Visible to Hidden Intangible Assets. Procedia - Social and Behavioral Sciences, 62, 682-688. https://doi.org/10.1016/j.sbspro.2012.09.116

Đuričin, D., \& Janošević, S. (2009). Strategijska analiza ljudskih resursa [Strategic analysis of human resources]. Economic Themes, 47(1), 1-46.

Dženopoljac, V., Janoševic, S., \& Bontis, N. (2016). Intellectual capital and financial performance in the Serbian ICT industry. Journal of Intellectual Capital, 17(2), 373-396. https://doi.org/10.1108/jic-07-2015-0068

Dzenopoljac, V., Yaacoub, C., Elkanj, N., \& Bontis, N. (2017). Impact of intellectual capital on corporate performance: evidence from the Arab region. Journal of Intellectual Capital, 18(4), 884-903. https://doi.org/10.1108/jic-012017-0014

Ghosh, S., \& Mondal, A. (2009). Indian software and pharmaceutical sector IC and financial performance. Journal of Intellectual Capital, 10(3), 369-388. https://doi.org/10.1108/14691930910977798

Gupta, K., \& Raman, T. V. (2020). Intellectual capital: a determinant of firms' operational efficiency. South Asian Journal of Business Studies, 10(1), 49-69. https://doi.org/10.1108/sajbs-11-2019-0207

Mehta, A. D., \& Madhani, P. M. (2008). Intangible assets-An introduction. The Accounting World, 8(9), 11-19.

Mention, A., \& Bontis, N. (2013). Intellectual capital and performance within the banking sector of Luxembourg and Belgium. Journal of Intellectual Capital, 14(2), 286-309. https://doi.org/10.1108/14691931311323896

Michalisin, M. D., Smith, R. D., \& Kline, D. M. (1997). IN SEARCH OF STRATEGIC ASSETS. The International Journal of Organizational Analysis, 5(4), 360-387. https://doi.org/10.1108/eb028874

Mukherjee, T., \& Sen, S. S. (2019). Intellectual Capital and Corporate Sustainable Growth: The Indian Evidence. Journal of Business Economics and Environmental Studies, 9(2), 5-15. https://doi.org/10.13106/jbees. 2019.vo19.no2.5

Naidenova, I., \& Parshakov, P. (2013). Intellectual capital investments: evidence from panel VAR analysis. Journal of Intellectual Capital, 14(4), 634-660. https://doi.org/10.1108/jic-01-2013-0011

Novićević, B., Antić, L., \& Stevanović, T. (2006). Upravljanje performansama preduzeća [Enterprises performances management. Niš: Ekonomski fakultet.

Pike, S., Fernström, L., \& Roos, G. (2005). Intellectual capital. Journal of Intellectual Capital, 6(4), 489-509. https://doi.org/10.1108/14691930510628780

Popkova, E. G., \& Haabazoka, L. (2019). The Cyber Economy as an Outcome of Digital Modernization Based on the Breakthrough Technologies of Industry 4.0. In The cyber economy: opportunities and challenges for artificial intelligence in the digital workplace (p. 3-10). Springer, Cham.

Pozdnyakova, U. A., Golikov, V. V., Peters, I. A., \& Morozova, I. A. (2019). Genesis of the revolutionary transition to industry 4.0 in the 21 st century and overview of previous industrial revolutions. In Industry 4.0: Industrial Revolution of the 21st Century., Springer, Cham., p. 11-19 
Prokofyev, S. E., Bratarchuk, T. V., \& Klimova, I. I. (2019). Perspectives on the Potential Application of Intelligent Machines in the Cyber Economy. In The cyber economy: opportunities and challenges for artificial intelligence in the digital workplace. Springer., Cham., p. 95-103.

Sardo, F., \& Serrasqueiro, Z. (2017). A European empirical study of the relationship between firms' intellectual capital, financial performance and market value. Journal of Intellectual Capital, 18(4), 771-788. https://doi.org/10.1108/ jic-10-2016-0105

SBRA - The Serbian Business Registers Agency. (2020). Financial statements of the research sample [data files]. Retrieved from http://pretraga3.apr.gov.rs/pretragaObveznikaFI

SBRA - The Serbian Business Registers Agency. (2020). STO NAJ... privrednih društava u 2018. godini [The top hundred enterprises in 2018]. Retrieved from https://www.apr.gov.rs/upload/Portals/0/GFI\%202019/STO_NAJ/ STO_NAJ_2018_16102019.pdf

Serenko, A., \& Bontis, N. (2013). Investigating the current state and impact of the intellectual capital academic discipline. Journal of Intellectual Capital, 14(4), 476-500. https://doi.org/10.1108/jic-11-2012-0099

Shui-ying, J., \& Ying-yu, W. (2008). The Contribution of Intellectual Capital to Firms' Sustainable Growth Ability: An Empirical Investigation Based on Listed Companies in China. 2008 International Conference on Information Management, Innovation Management and Industrial Engineering, 394-397. https://doi.org/10.1109/ICIII.2008.245

Sukhodolov, Y. A. (2019). The notion, essence, and peculiarities of industry 4.0 as a sphere of industry. In Industry 4.0: Industrial Revolution of the 21 st Century Springer, Cham., p. 3-10.

Wang, Z., Wang, N., Cao, J., \& Ye, X. (2016). The impact of intellectual capital - knowledge management strategy fit on firm performance. Management Decision, 54(8), 1861-1885. https://doi.org/10.1108/md-06-2015-0231

Xu, J., \& Wang, B. (2018). Intellectual Capital, Financial Performance and Companies' Sustainable Growth: Evidence from the Korean Manufacturing Industry. Sustainability, 10(12), 4651. https://doi.org/10.3390/su10124651

Xu, X. L., Chen, H. H., \& Zhang, R. R. (2020). The Impact of Intellectual Capital Efficiency on Corporate Sustainable Growth-Evidence from Smart Agriculture in China. Agriculture, 10(6), 199. https://doi.org/10.3390/ agriculture 10060199

Xu, X. L., Li, J., Wu, D., \& Zhang, X. (2021). The intellectual capital efficiency and corporate sustainable growth nexus: comparison from agriculture, tourism and renewable energy sector. Environment, Development and Sustainability, 23(11), 16038-16056. https://doi.org/10.1007/s10668-021-01319-x

Zéghal, D., \& Maaloul, A. (2010). Analysing value added as an indicator of intellectual capital and its consequences on company performance. Journal of Intellectual Capital, 11(1), 39-60. https://doi.org/10.1108/14691931011013325

\section{UTICAJ NEMATERIJALNE AKTIVE NA ODRŽIVU STOPU RASTA PREDUZEĆA U REPUBLICI SRBIJI}

Digitalna ekonomija objedinjuje dvojaku tipologiju resursa u preduzećima, koji mogu biti materijalni i nematerijalni. Jezikom računovodstva, reč je o materijalnoj i nematerijalnoj aktivi. Usled involviranja digitalnih tehnologija u preduzećima do izražaja dolazi nematerijalna aktiva ili intelektualni kapital. Održivi rast preduzeća u Srbiji je od izuzetnog značaja kako za menadžment, tako $i$ za eksterne interesente. U predstavljenom radu se ispituje uticaj nematerijalne aktive, formatirane VAIC modelom, na održivu stopu rasta (eng. Sustainable growth rate, u daljem tekstu SGR) preduzeća u Srbiji. Odabrana lista preduzeća odnosi se na najprofitabilniji sektor naše privrede ocenjen prema Agenciji za privredne registre za 2018. godinu. U cilju potvrđivanja hipoteza, sintetički metod, metod analize i metod korelacije je upotrebljen. Dokazan je značajan pozitivan uticaj nematerijalne aktive na održivu stopu rasta preduzeća i negativan uticaj fizičke aktive, koji međutim nije statistički značajan. Budući da u našoj zemlji nije zabeleženo istraživanje koje rasvetljava korespondiranje nematerijalne aktive i SGR, studija u ovu svrhu ima snažan praktični značaj. Navedeni rezultati predstavljaju ujedno i orijentacionu tačku našoj privredi $i$ budućim preduzetnicima na putu ka intenzivnom involviranju nematerijalne aktive u preduzećima.

Ključne reči: nematerijalna aktiva, digitalna ekonomija, održiva konkurentska prednost, održiva stopa rasta 